\title{
Affective Characteristics and Teaching Skills of English Language Teachers: Comparing Perceptions of Elementary, Secondary and High School Students
}

\author{
Ebru Melek Koç \\ Academic Writing Centre, Izmir Institute of Technology, Izmir, Turkey \\ Email: ebrukoc@iyte.edu.tr \\ Received August $9^{\text {th }}, 2012$; revised September 10 $0^{\text {th }}, 2012$; accepted September $26^{\text {th }}, 2012$
}

\begin{abstract}
The present study aims to investigate the elementary, secondary and high school students' perceptions on a good language teacher. The participants are 365 Turkish school students who are learning English as a foreign language. The present study has revealed that most of the student groups generally differ in terms of issues related to teaching skills when compared with the issues related to the affective skills. In the present study it has been also found that what students expect from a good English teacher is to have the ability to maintain discipline, motivate students, learn about the learner' needs and establish good relations with them. The study also reveals striking results with respect to classroom discipline and teacher subject knowledge.
\end{abstract}

Keywords: Good Teacher; English Language Teacher; Affective Characteristics; Teaching Skills

\section{Introduction}

The teacher education system aims to train qualified and effective teachers. Since "effective teacher" and "good teacher" are overlapping concepts, in the present study these two constructs will refer to each other. Miller (1987) states four major issues related to the concept of "being an effective teacher": 1) affective characteristics; 2) teaching skills; 3) academic knowledge; and 4) classroom management. Affective characteristics refer to issues such as establishing positive relations with the students and showing interest in learners. Teaching skills consists of teacher's knowledge about the subject, pupils, curriculum and also effective use of the teaching methods and materials. Academic Knowledge addresses teachers' subject knowledge and the ability to teach their subject to their students.

Kounin (1970) defines "effective teachers" as those who "accurately handle inappropriate student behaviour, manage competing or developing events, more smoothly through instruction, maintain appropriate pacing, and maintain a group focus". According to Kounin (ibid) the abilities accepted from an effective teacher are the ability to handle student misbehaviour appropriately, to create and manage a stimulating competitive environment, to give clear instruction to pace and maintain a focused group work. He also points out that the most specific feature of an effective teacher is to keep students focused on learning and to reduce classroom disruption.

An effective teacher should also motivate the learners. In Walter (2000) it is indicated that giving students more control over the learning process increases motivation. Similarly, Dickinson (1987) comments as follows: "If the learner is prevented from using the favoured techniques, this is likely to seem to her to reduce her learning effectiveness and so be demotivating".

Stricland (1998) rather than defining "the characteristics of an effective teacher", has described "bad teachers" and referred to them as teachers who lack field knowledge and good classroom control, who cannot discover the learning problems of learners, who have obsessions on teaching and do not have certain goals. In addition, not caring about the students and not interacting with them is another feature of a bad teacher. Bad teachers do not have presentational skills, in other words, they teach too fast or too slow; they are too authoritative or lack discipline.

Thomas and Montomery (1998) investigated grades 2, 3, 4, 5, and grade students' views on the quality of teaching. They did interviews, and used personal journals and reflective notes as data collection instruments. They have stated four dimensions of good teaching: caring; understanding, fun and loving. What is interesting about these results is that all these dimensions relate to the affective characteristics.

Taylor (1962) analysed 1379 essays by primary and secondary school pupils on "a good teacher" and "a poor teacher" and constructed a checklist which was filled by 867 children. The results revealed that students' "good teacher" concept related with mostly to teaching skills $(40 \%)$ and personal qualities $(25 \%)$.

Vollmer and Creek (1988) used SPI (Student Perception Instrument) which evaluated teacher effectiveness in two dimensions: competencies in classroom behaviour and interpersonal skills. These two concepts seem to correspond with the concepts "teaching skills" and "affective characteristic".

Wragg and Wood (1984) constructed a study with high school children whose age ranged from 12 to 16 and who are at different grades. The results showed significant difference in terms of grade level. Most of the students (75\%) preferred teachers who were good listeners, explained things clearly in the class and helped them learn a lot.

If teachers are aware of what the students expect from them the teachers will be more successful in meeting the students' 
needs, thus effective teaching will be achieved. As a measurement tool "students' voice" was claimed to be valuable in providing insights to "what a good teacher is". Students" perceptions on "the characteristics of a good teacher" have been a neglected area. Taking this fact into consideration, the present study aims to fill this gap. Students' voices may provide a deeper insight into the concept of the features of a good language teacher, by the help the present study, teachers will be provided with the thoughts of their pupils about what their students expect from them as teachers. The results of the study will help the English language teachers in meeting the expectations of the students, which is likely to lead to a more effective language teaching. The present study aims to investigate the research questions below:

1) What are the elementary, secondary and high school students' perceptions on "a good English language teacher"?

2) Are there any differences among the perceptions of the elementary, secondary and high school students in terms of their perception of "a good English language teacher"?

\section{Methodology}

\section{Participants}

The participants of the present study are 365 Turkish school students who are learning English as a foreign language and categorised into three groups (Table 1). The first group is elementary school students who are at the 1 st, 2 nd, 3rd and 4th grades and whose ages differ from 7 to 11 . The second group consists of secondary school students who are at the 7th and 8th grades and whose ages differ from 12 to 14. And the last group of the students is the high school students at the 10th and 11th grades. The age of high school students range from 16 to 17 .

\section{Data Collection Instrument}

The data was elicited by means of a questionnaire constructed by the researcher. In order to achieve the content validity, the questionnaire items were analysed by two field experts from the department of English Language Teaching. Taking the comments of these two experts into consideration some of the items were revised, modified or omitted. Moreover, to enrich the validity of the questionnaire and to achieve face validity, a pilot study was constructed. The purpose of the pilot study was to find out the ambiguities if there were any. Five students from each group of students participated in the pilot study. In the pilot study some of the elementary students indicated that they had difficulty in understanding the 5-point agreement scale. Thus, the 5-point agreement scale was modified and changed into a 5-point "degree of importance" scale. In the questionnaire a 5-point degree scale was used to analyse the perceptions of the learners. In all the items 1 was assigned "not important",

Table 1.

Categorisation of the participants in terms of number/gender and level of school.

\begin{tabular}{lccc}
\hline & Female & Male & Total \\
\hline Group I: Elementary & 46 & 54 & 100 \\
Group II: Secondary & 60 & 60 & 120 \\
Group III: High & 82 & 63 & 145 \\
Total & 188 & 177 & 365 \\
\hline
\end{tabular}

2 "has little importance", 3 "undecided", 4 "important" and 5 "very important".

The questionnaire has 24 items. Items $1,4,7,8,9,10,11,12$, $13,15,16,17,18,19,20$ and 23 include statements which refer to a teacher's teaching ability, classroom management skills and subject knowledge teaching. Therefore, the sub-category covering these items is named as "Teaching Skills". On the other hand items 2, 3, 4, 6, 14, 21, 22 and 24 are associated with a teacher's personal characteristics and the sub-category covering these items is named "affective characteristics". The questionnaire is designed in a 5-point agreement degree scale was in which items were assigned from "not important (1)" to "very important (5)".

\section{Data Collection Procedures}

Before data collection, permission is taken from the school ministers to collect data in their schools and participants are provided a participant consent form in which it is indicated that their participation is voluntary and data provided by them is confidential, they can withdraw their data anytime, by which the author has fulfilled the technical requirements necessary to demonstrate the use of ethical procedures in researching human participants.

The questionnaires were administered to the elementary, secondary and high school students at 6 state schools by the researcher. A second visit was done to these schools in order to collect the questionnaires back. The total data collection procedure lasted for four weeks.

\section{Data Analysis}

The frequencies and mean scores of each item in the questionnaire were calculated to find out the perceptions of the three groups of students. The statistical test of analysis of variance (ANOVA) compares several group means simultaneously. If one independent variable is included, the ANOVA is one-way ANOVA; if two independent variables are included in an ANOVA, the analysis is called two-way ANOVA (Hatch \& Farhady, 1982; Smith \& Glass, 1987; Wiersma, 1995). In the present study one-way ANOVA is used since there is only one independent variable (school level). In addition to ANOVA a post-hoc test of LSD test (Least significant Difference) is used to determine which student groups have significant difference with regard to the each questionnaire item.

\section{Results}

The results of each research question and the related discussion will be provided in a unified form.

Research question: What are the elementary, secondary and high school students' perceptions on "a good language teacher"?

The results will be presented under two main categories: 1) Teaching Skills and 2) Affective Characteristics. The results of the mean scores, standard deviation and $p$ value for each item are presented in Table 1. According to the students' overall mean scores for all items (Table 2), characteristics of a good English language teacher which received the ten highest mean scores, the students think that a good English language teachers is someone who:

- does not discriminate among the students;

- is patient; 
- is good at pronunciation;

- takes the attention of the students in the classroom;

- teaches well;

- has good affairs with the students;

- creates and entertaining learning atmosphere;

- is kind to his/her students;

- asks the views of the his/her students when organising the classroom activities;

- has the ability to participate his/her students in the lesson. According to the students' ratings the most important quality of a good English language teacher is that he/she should not discriminate among the students and be patient, which is related to affective characteristics. Blishen (1996) found that according to the pupils the most important quality of a good teacher is personality. He found that understanding and patience, the ability to pay attention to the pupil, the ability to develop good relations with the parents, and politeness were the qualities of a desired teacher. Similarly Friedman and Korngold (1993) found that a good teacher was described as a teacher who develops good interpersonal relations. Although the first two characteristics which received the highest score from the three students groups belong to the sub-category "affective characteristics", the characteristics of a good teacher stated above equally rep- resent the features of both "teaching skills" and "affective characteristics". This shows that according to the students' features belonging both the "teaching skills" and "affective characteristics" are discriminating factors for being a good teacher.

The lowest overall mean scores of the students were calculated (Table 2). For the items 2, 7, and 12. The mean overall mean scores of the students for these items are relatively 3.79 , 3.43, and 3.17. Although the results does not indicate that the teachers who "organize activities such as games and songs in the classroom", "assign homework", and "praise the students in the classroom" are not good teachers; it seems to indicate that these characteristics of an English language teacher are not as appreciated as the others characteristics stated in the questionnaire.

In general the results seem to indicate that the elementary, secondary and high school students perceive the affective characteristics of a teacher as a dominant feature of a good English language teacher (Table 3).

Research Question 2: Are there any differences among the perceptions of the elementary, secondary and high school students in terms of their perception of "a good language teacher"?

The LSD test analysis showed that the students groups

Table 2.

Perceptions of student groups to the 24 questionnaire items in means.

\begin{tabular}{|c|c|c|c|c|c|}
\hline & Item Statements & Group I & Group II & Group III & Overall \\
\hline \multirow{6}{*}{ 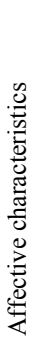 } & Item 5: A good English teacher should not discriminate among the students. & 4.90 & 4.80 & 4.83 & 4.84 \\
\hline & $\begin{array}{l}\text { Item 14: A good English teacher should be patient with the students and } \\
\text { should explain the subject to them when they don't understand it. }\end{array}$ & 4.76 & 4.86 & 4.83 & 4.82 \\
\hline & Item 21: A good English teacher should have good affairs with the students. & 4.64 & 4.68 & 4.54 & 4.61 \\
\hline & Item 3: A good English teacher should be kind to his students. & 4.75 & 4.45 & 4.49 & 4.55 \\
\hline & Item 6: A good English teacher should know all his students very well. & 4.45 & 4.45 & 4.44 & 4.44 \\
\hline & Item 22: A good English teacher should be contact with the families of the students. & 4.13 & 4.09 & 3.33 & 3.80 \\
\hline \multirow{14}{*}{ 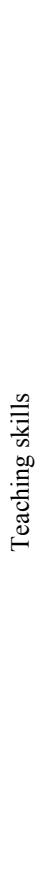 } & $\begin{array}{l}\text { Item 2: A good English teacher should praise me and say nice words } \\
\text { in the class when I give the right answer. }\end{array}$ & 3.94 & 3.00 & 2.77 & 3.17 \\
\hline & Item 8: A good English teacher should be good at pronunciation. & 4.79 & 4.66 & 4.66 & 4.70 \\
\hline & Item 23: A good English teacher should teach well. & 4.60 & 4.66 & 4.62 & 4.63 \\
\hline & $\begin{array}{l}\text { Item 4: A good English teacher should be able to create an entertaining } \\
\text { atmosphere to carry out the class activities. }\end{array}$ & 4.41 & 4.56 & 4.66 & 4.56 \\
\hline & Item 19: A good English teacher should have his students participate in the lesson. & 4.61 & 4.68 & 4.29 & 4.50 \\
\hline & Item 9: A good English teacher should do research on his subject and improve himself. & 4.54 & 4.50 & 4.44 & 4.48 \\
\hline & Item 16: A good English teacher should maintain discipline in the classroom. & 4.41 & 4.54 & 4.13 & 4.34 \\
\hline & Item 10: A good English teacher should consult to other lesson sources in addition to text books. & 4.40 & 4.14 & 4.23 & 4.24 \\
\hline & Item 18: A good English teacher should make a lesson plan. & 4.60 & 4.45 & 3.98 & 4.23 \\
\hline & Item 17: A good English teacher should manage to keep the class in silence. & 4.32 & 4.45 & 3.98 & 4.23 \\
\hline & Item 15: A good English teacher should have a great deal of teaching experience. & 4.63 & 4.36 & 3.80 & 4.21 \\
\hline & Item 13: A good English teacher should speak in Turkish most of the class time. & 4.16 & 3.96 & 4.09 & 4.07 \\
\hline & $\begin{array}{l}\text { Item 12: A good English teacher should have the class sing songs and } \\
\text { play some games relevant to the subject. }\end{array}$ & 4.21 & 3.60 & 3.60 & 3.76 \\
\hline & Item 7: A good English teacher should assign homework to the students. & 3.66 & 3.51 & 3.20 & 3.43 \\
\hline
\end{tabular}


showed significance difference regarding the items $2,3,12,15$, 16, 17, 18, 19, 22 and 24 (Table 4). The results will be stated in more detail for each significant item under the related subcategory.

\section{Teaching Skills}

This sub-category constitutes items $1,4,7,8,9,10,11,12$, $13,15,16,17,18,19,20$, and 23 . According to the analysis the student teachers in their perceptions in regard to characteristics of good English language teachers for items 12, 15, 16, 17, 18 and 19.

The results for item 15 indicated that all the elementary school $(\mathrm{M}=4.63)$ and secondary school students $(\mathrm{M}=4.36)$ profoundly believe that to be a good teacher it is important to have a great deal of teaching experience (Table 2). However, high school students $(\mathrm{M}=3.80)$ do not seem to believe this concept as deeply as the elementary and secondary school students. The results of the ANOVA $(p<0.000)$ test reveal that there is a significant difference among student groups at the level of 0.05 . According to the LSD Test, there is a significant difference between Group I and Group III $(p<0.0000)$ and also between Group II and Group III $(p<0.0000)$ at the level of 0.05 (Table 4).

With respect to item 12 stating "A good English teacher should have the class sing songs and play games relevant to the subject", Table 2 clearly shows that elementary school students $(\mathrm{M}=4.21)$ deeply feel that to be a good English teacher it is very important to have the class sing songs and play some games when compared with secondary and high school children. The one-way ANOVA results $(p<0.000)$ indicate the groups significantly differ in terms of their responses to Item 12 at the level of 0.05 . According to the LSD Test (Table 4), there is a significant difference between Group I and Group II $(p<$ $0.0000)$; and Group I and Group III $(p<0.000)$ at the level of 0.05 , which means the elementary school students profoundly think that one of the features of a good English teacher is to have the class sing songs and play games relevant to the subject whereas the secondary and the high school students think that these activities are not so important.

With regard to item 18 which states that "a good English teacher should make a lesson plan", all the student groups ( $\mathrm{M}=$ 4.28) appear to have a high tendency to believe that it is important to make a lesson plan considered to be one of the features of a good English teacher. The results the ANOVA test $(p<$ 0.000 ) indicate a significant difference among the three groups at the level of 0.05 . Also, LSD test results indicate that such a significant difference is between Group I and Group III $(p<$ $0.0000)$; and Group II and Group III $(p<0.00001)$. This means while the elementary and the secondary school students profoundly believe making a lesson plan is an important characteristic of a good language teacher, high school students do not seem to believe this concept as profoundly as the other ones.

With respect to item 4, the results appear to show all the student groups $(\mathrm{M}=4.56)$ deeply believe that to be a good language teacher it is important to carry out the class activities in an entertaining atmosphere. What is interesting is that as the grade level of the students' increases, students' belief of the importance of carrying out the class activities in an entertaining atmosphere considered one of the features of a god English teacher seems to increase [(Elementary: 4.41, Secondary: 4.56; High: 4.66)], which means while high school children seem to think that carrying out the class activities in an entertaining atmosphere is very important, the elementary school children find it less important.

With respect to item 19 which states that "a good English teacher should have his students participate in the lesson", all the student groups $(\mathrm{M}=4.50)$ think that having the students participate in the lesson is important if a teacher wants to be considered as a good one. The High school students $(M=4.29)$ seem to give less importance to this conception. Analysis of variance $(p<0.000)$ indicate that there is a significant difference among the three student groups at the level of 0.05 . The LSD test results also reveal that these significant differences are between Group I and Group III $(p<0.006)$; and Group II and Group III $(p<0.00006)$ at the level of 0.05 , which means the elementary and the secondary school students think a good

Table 3.

Each student group's overall mean scores for the two sub-categories.

\begin{tabular}{ccc}
\hline & Affective Characteristics & Teaching Skills \\
\hline Group I & 4.53 & 4.36 \\
Group II & 4.95 & 4.04 \\
Group III & 4.20 & 4.14 \\
Overall & 4.56 & 4.18 \\
\hline
\end{tabular}

Table 4.

The list of LSD (least significance degree) test scores for items which are significant at $p<0.05$.

\begin{tabular}{|c|c|c|c|c|}
\hline Sub-Category & Item No & $\begin{array}{l}\text { Elementary-Secondary School students } \\
\text { (Group I \& Group II) }\end{array}$ & $\begin{array}{l}\text { Elementary-High School students } \\
\text { (Group I \& Group III }\end{array}$ & $\begin{array}{l}\text { Secondary-High School students } \\
\text { (Group II \& Group III) }\end{array}$ \\
\hline \multirow{6}{*}{ Teaching Skills } & Item 15 & & 0.000 & 0.000 \\
\hline & Item 12 & 0.000 & 0.000 & \\
\hline & Item 18 & & 0.000 & 0.000 \\
\hline & Item 19 & & 0.006 & 0.000 \\
\hline & Item 16 & & & 0.000 \\
\hline & Item 17 & & & 0.001 \\
\hline \multirow{4}{*}{ Affective Characteristics } & Item 2 & 0.000 & 0.000 & \\
\hline & Item 3 & 0.009 & & \\
\hline & Item 22 & & 0.000 & 0.000 \\
\hline & Item 24 & & 0.007 & \\
\hline
\end{tabular}


English teacher should have his/her students participate in the lesson whereas the high school students seem to find it less important.

It is a surprising finding that student groups appear to believe a good English teacher should maintain discipline (Item 16, M $=4.34$ ). Of three groups of students, high school students seem to show the lowest degree of importance for item 16. An empirical study of Wragg (1989) also supports this finding. Wragg has found the fact that teachers are expected to be firm but fair. Teachers who are bossy or punitive are not esteemed, but neither the ones who are too permissive, which means the concept of maintaining discipline in the classroom is deeply believed to be an important feature of a good English teacher by the elementary and the secondary school students while the high school student find it a less important feature.

Similarly, for item 17 which states "a good English teacher should manage to keep the class in silence", the statistical findings reveal that the groups. This means, high school students do not believe that keeping the class in silence is a characteristic of a good language teacher as profoundly as the elementary and secondary school students do.

\section{Affective Characteristics}

The second main part covers items 2, 3, 5, 6, 14, 21, 22 and 24.

Results for item 2 indicate that as the grade level of the students increases, they show lower tendency for being praised (Elementary: 3.9 ; Secondary: 3.0 ; High: 2.7). ANOVA results indicate that there is a significant difference among groups $(p<$ $0.000)$ at the level of 0.05 . Table 4 indicates that there are significant differences among groups and these such a significant differences exist between 1) Group I and Group II $(p<0.000)$ and 2) Group I and Group III $(p<0.000)$ at the level of 0.05 , which means the elementary school students consider being praised by a teacher as a feature of a good English teacher while the high school students do not consider it so important and the secondary school students cannot decide whether a good teacher should praise them or not. This finding is supported by a study (cited in Cullingford, 1995) which has investigated the effect of individual praising on elementary school children. It has been found that when the use of private praise increases, the elementary school children' academic achievement improves 20 per cent.

With regard to item 3 , the elementary $(\mathrm{M}=4.75)$, secondary $(\mathrm{M}=4.4)$ and high school students $(\mathrm{M}=4.4)$ believe that a good English teacher should to be kind to his/her students.

Regarding item 22, results indicate that all the students with a mean score of 3.89 believe that a good teacher should be in contact with the families of the students. It is interesting that as the grade level increases, the degree of perception of importance decreases. While the elementary students $(\mathrm{M}=4.13)$ have the strong belief of importance for item 22, the high school students $(\mathrm{M}=3.33)$ have the lowest. ANOVA findings indicate that there is a significant difference among the student groups $(p<0.000)$ at the level of 0.05 . LSD test indicates that there is a significant difference between elementary school students and high school students $(p<0.000)$ and between secondary school students and high school students $(p<0.000)$ at the level of 0.05 .

With regard to item 24 which states that "a good English teacher should take the views of the students into consideration in class activities", all the student groups believe it is important $(\mathrm{M}=4.54)$ to take the students' views into consideration of the students in the class activities. This finding is also supported by Wragg and Wood's study (1984). According to the results of Lin et al., 2000 (in Muijs \& Reynolds, 2001) giving students authority in the classroom can improve classroom climate and encourage students to participate in the classroom.

Of the three student groups, the elementary school student group $(\mathrm{M}=4.68)$ and the secondary school student group $(\mathrm{M}=$ 4.62) seem to give more importance to item 24 when compared with the high school students $(M=4.38)$. ANOVA (LSD test) findings (see Table 3 ) indicate that the groups show significant difference in term of their perceptions for item $24(p<0.000)$ at the level of 0.05 . The LSD test findings also show that there is a significant difference between: Group I and Group III $(p<$ 0.007 and Group II and Group III (0.02) at the level of 0.05 . This means the high school students do not think taking the views of the students in class activities, which is considered as a feature of a good English teacher, as important as the elementary and secondary school students do.

With regard to item 5, all the student groups seem to have the highest perception degree of importance with a mean score of 4.90. This finding is likely to show that what the students in three groups appreciate most is when the teacher does not discriminate among the students and is fair to them.

The second teacher characteristic which received the second highest mean score is "being patient with the student (item 14)" for which all the student groups indicate a very high perception degree of importance is item $14(\mathrm{M}=4.82)$. This appears to show that an English teacher's being patient with students and explaining the subject to them when they do not understand is an important characteristic of a good English teacher. Similar to this, Hollis (1935, cited in Wragg \& Wood) analysed the rank order of teachers' attitudes expected by students and found that the highest esteem was given to the teachers' ability to explain the difficulties in a patient way when the students asked for the teacher to do.

In summary, although all the student groups believe it is important for a good teacher to create an entertaining atmosphere, have the students participate in the lesson, be kind to the students, take the views of the students into consideration in class activities, manage classroom discipline and consult other sources in addition to text books, they do not seem to find it very important at all when the teacher assigns homework to the students, praise the students by saying nice words in the class.

It is also striking that the student groups show significant difference with regard to the degree of perception of importance for items $7,2,18,22,24$ and 15 . As the grade level increases, the students find teacher's being experienced in his/her branch, teacher's assigning homework to the students, teacher's praising students, teacher's making a lesson plan, teacher's being in contact with the families of the students, teacher's having the class sing songs and play games, teacher's taking the students' views into consideration in class activities less important characteristics of a good teacher.

\section{Discussion}

The purpose of the present study is to bring into focus the EFL learners' perceptions of "a good English Teacher". The present study has revealed that most of the student groups generally differ in terms of issues related to teaching skills when 
compared with the issues related to the affective skills. This result is consistent with Taylor (1962)'s cited in Wrag and Wood, p. 80) study who investigated the primary and secondary school students' views on "a good teacher". The analysis of the students' essays revealed that students' "good teacher" concept related with mostly to teaching skills $(40 \%)$ and personal qualities $(25 \%)$.

In the present study it has been also found that what students expect from a good English teacher is to have the ability to maintain discipline, motivate students, learn about the learner' needs and establish good relations with them. These findings are also supported with many studies in the related field (Barkhuizen, 1998; Stephens \& Crawly, 1994; Burnett \& Meachem, 2002).

Another finding is related to subject knowledge. Elementary school children believe that having a great deal of teaching experience is an important characteristic of being a good English teacher. On the other hand, high school students do not seem to be appreciating the belief as strongly as the elementary school children do. However, literature seems to support the elementary school children's view. In teacher education programmes teachers are exposed to a great deal of theory, and given little chance to practise. Most of the time without having time to integrate these two, they begin teaching. Burden (1990) says that novice teachers, even though they have completed a teacher training programme, have limited knowledge of teaching activities; have limited knowledge about the teaching environment and an image of the teacher as authority; have limited professional insights and perceptions; and have feelings of uncertainty, confusion. Majority of novice teachers begin their careers with a feeling of "not adequate teacher", rather than "a bad teacher" (Newport \& John, 1996). Thus, it is difficult to believe that novice public school teachers who have received considerable training in teaching, and who have one or two years of teaching experience, could be considered to meet the standards of an effective teacher.

The study also reveals striking results with respect to classroom discipline. Elementary, secondary and high school students believe that one of the characteristics of a good language teacher is to maintain discipline. "Classroom Concept" is strongly integrated with "classroom management". Also, "effective teaching" and "classroom management" are two strongly related issues. For effective teaching and to be an effective teacher, good classroom management is required (Silvestri, 2001; Woolfolk, 1998; Wragg \& Wood, 1984). According to research on different aspects of classroom management, most of the teachers, especially the novice teachers seem to lack such characteristics that an effective language teacher should have and regard classroom discipline [management] as their most serious problem (Silvestri, 2001). Similarly, Woolfok (1998) states some concerns of novice teachers such as classroom discipline, motivating students, and accommodating differences among students. Teachers, especially the novice ones, should be aware of the fact that teachers who regard classroom management as a process of achieving and also maintaining effective learning are better classroom managers than teachers who regard it as being "authoritative and maintaining discipline".

The other striking finding of the present study is that while the grade level of the students increases the students' strong perception about the significance of making a lesson plan considered an important feature of a good English teacher decreases. That is, the elementary school students are likely to give more importance to doing homework than high school students and to some extend the elementary school students may regard teachers' making lesson plan as their doing homework which occupies most of their time.

Another set of finding is related with the appropriate usage of materials and activities. Classroom entertainment activities such as games, jokes, stories, and songs produce enjoyment. Ur (1996) points out that such kind of entertainment arouses the interest in the task and motivates students. They encourage students to interact and communicate. The use of such activities both increases the co-operation and competition in the classroom. Thus, a successful, joyful and enthusiastic learning is achieved in the language classroom. Similarly, using songs create a non-threatening atmosphere for students who often feel anxious to speak English in a formal classroom setting (Lo \& Fai Li, 1998). The present study interestingly reveals that only elementary school students seem to like activities such as singing song and games. On the contrary, high school students do not appear to have such a strong feeling about these activities. They rather prefer translation, vocabulary drills. This is possibly due to the fact that elementary school students do not have sufficient English proficiency in terms of both vocabulary size and grammar knowledge. Similarly, Liu and Littlewood (1997), too, in their study report that one of the reasons why the elementary students are reluctant to participate in the classroom activities is that they have limited experience in English. On the other hand, high school students have a bit more considerable amount of English proficiency activities requiring reading, writing and grammar when compared with the elementary students. "Age of the learners" is likely to be another discriminating factor. For example, while games motivate and attract the attention of the primary school students, it is not an appropriate activity for teenage students.

Another finding of the study is that students think it is important for a good language teacher to consult other teaching aids in addition to text books. This may be due to the fact that textbooks used in state schools are likely to be out of date and cannot serve for a variety of activities to motivate students to learn English.

Another striking finding of the study is that secondary and high school students strongly believe that it is not a characteristic of "a good" teacher to praise his students with encouraging words. This finding is striking in that it is a general idea among teachers that students like to be praised. However, high school students do not seem to appreciate it. One possible explanation can be that the teachers do not know which type of praise is appropriate for their students. Muijs and Reynolds (2001) though claim that teacher praise is one of the most frequently used forms of rewards, not all praise is effective for different grades. For the elementary school children stars, badges and teacher's praise with nice words are more effective while for secondary and high school students privileges such as responsible roles in the classroom are more effective.

All the student groups appreciate teachers' taking the views of the students in the classroom as an important characteristic of a good English teacher, which is another finding of the present study. What is more striking is that as the grade level of students' increases, their agreement scores to the item decrease. This may due to that elementary students are more willing to participate and take responsibilities in classrooms when compared with students at higher grades. 


\section{Conclusion}

\section{Implications of the Study}

The study serves as a good source for language teachers to compare their own perceptions and believes with that of the students. Once language teachers are aware of their students' perceptions, they can plan and implement behaviours and activities that would encourage learners to get involved more in the English language process, therefore lead to more language learning and positive attitudes towards their teachers.

In the present study, it has been revealed that students expect a good English teacher to have the ability to maintain discipline, motivate students, to learn about the learners' needs and establish good relations with them. Muijs and Reynolds (2001) have found that good classroom discipline and a positive classroom atmosphere are strongly related to each other, which suggests that in practice effective teachers are able to strike the right balance between two.

As trainees are likely to lack knowledge of the characteristics of a good EFL teacher, such a study would likely provide teacher education programmes with an opportunity to develop trainees' notions of being an effective EFL teacher.

\section{Suggestions for Further Research}

It is important to highlight that in this study only the perceptions of Turkish EFL learners' have been taken under investigation. With respect to this, a further research which compares teachers and students in terms of their perceptions of an effective teacher can be suggested.

The study also shows that all the group students feel it is an important characteristic of a good English teacher to have pair-work and group-work activities. However, teachers have some concerns when performing group work activities in the classroom in terms of controlling the students (Daloğlu, 2001). This concern can be partly due to the fact that the teacher education programmes focus on a more theoretical education and cannot provide enough opportunities to put such theoretical knowledge into practice. Johnson (1996) supports this and comments on it as follows: "teachers get too much theory, however too little practice and can not put into the theory into effective classroom practice.

Research has shown that perception of learners and perceptions of teachers do no match (Block, 1994; Kumaravadivelu, 1991). Therefore, further research should be conducted to investigate teachers' concerns in order to help them gain the ability of co-ordinating students better for collaborative work. The teacher education system aims to train teachers who are qualified and who can achieve effective teaching. Taking this fact into such a development in the curriculum, another suggestion for further research is that a study should be conducted to investigate the role and the effectiveness of the new curriculum in terms of to what extend it has helped the students to integrate theory and practice. room teaching/learning activities in a South African context. TESOL Quarterly, 32, 85-108. doi:10.2307/3587903

Blishen, E. (1969). The school that I'd like. London: Penguin.

Block, M. E. (1994). A teacher's guide to including students with disabilities in regular physical education. Baltimore: Paul H. Brooks

Burden, P. R. (1990). Teacher development. In W. R. Houston, M. Haberman, \& J. Sikula (Eds.), Handbook of research on teacher education (pp. 311-327). New York: Macmillan.

Burnett, P., \& Meacham, D. (2002). Measuring the quality of teaching in elementary school classrooms. Asia-Pacific Journal Teacher Education, 30, 141-153.

Cullingford, C. (1995). The effective teacher. London: Cassell. doi:10.1080/13598660220135658

Daloğlu, E. M. (2001). Classroom interaction and collaborative learning. 1st East Mediterranean University International Conference, Gazimagusa, 2-4 May 2001

Dickinson, L. (1987). Self-instruction in language learning. Cambridge: Cambridge University Press.

Hatch \& Farhady (1981). Research design and statistics for applied linguistics. Rowley, MA: Newburry.

Friedman, Y., \& Korngold, N. (1993). Reciprocal relations between teachers and students: The students' point of view. Jerusalem: Henrietta Szold Institute.

Johnson, K. (1996). The role of theory in L2 teacher education. TESOL Quarterly, 30, 765-771.

Kumaravadivelu, B. (1991). Language-learning tasks: Teacher intention and learner interpretation. ELT Journal, 45, 98-107. doi:10.1093/elt/45.2.98

Kounin, J. S. (1970). Discipline and group management in classrooms. New York: Holt, Rinehart and Winston.

Liu, N. F., \& Littlewood, W. (1997). Why do many students appear reluctant to participate in classroom learning discourse? System, 25, 371-384. doi:10.1016/S0346-251X(97)00029-8

Lo, R., \& Fai Li, H. C. (1998). Songs enhance learner involvement. English Teaching Forum, 36, 8-11.

Miller, P. (1987). Ten characteristics of a good teacher. English Teaching Forum, 25, 40-41.

Muijs, D., \& Reynolds, D. (2001). Effective teaching: Evidence and practice. London: Paul Chapman Publishing.

Silvestri, L. (2001). Pre-service teachers' self-reported knowledge of classroom management. Education, 121, 575-581.

Smith, M. L., \& Glass, G. V. (1987). Research and evaluation in education and the social sciences. Bergen County: Englewood Cliffs.

Stephens, P., \& Crawley, T. (1994). Becoming an effective teacher. England: Stanley Thorns.

Strickland, G. (1998). Bad teachers: The essential guide for concerned parents. New York: Pocket Books.

Taylor, P. (1962). Children's evaluations of the characteristics of a good teacher. British Journal of Educational Psychology, 32, 258266. doi:10.1111/j.2044-8279.1962.tb01769.x

Thomos, J. A., \& Montgomery, P. (1998). On becoming a good teacher: Reflective practice with children's voices. Journal of Teacher Education, 49, 372-380. doi:10.1177/0022487198049005007

Ur, P. (1996). A course in language teaching: Practice and theory. Cambridge: Cambridge University Press.

Vollmer, M. L., \& Creek, R. J. (1988). Measurement of student perceptions of teaching competencies. Retrieved from ERIC DIGEST, NO: 303453, on December 9, 2010.

Woolfolk, A. E. (1998). Educational psychology. Boston: Allyn \& Bacon.

Wiersma, W. (1995). Research methods in education: An introduction. Boston: Allyn \& Bacon.

\section{REFERENCES}

Barkhuizen, G. (1998). Discovering learners' perceptions of ESL class- 